\title{
Age and growth of the endangered fan mussel Pinna nobilis in the western Mediterranean Sea
}

\author{
J.R. García-March ${ }^{\text {a, }}$, S. Hernandis ${ }^{\text {a,b }}$, M. Vázquez-Luis ${ }^{c}$, P. Prado ${ }^{\mathrm{d}}$, S. Deudero ${ }^{c}$, N. Vicente ${ }^{\mathrm{e}}$, \\ J. Tena-Medialdea ${ }^{\text {a }}$ \\ ${ }^{a}$ Instituto de Investigación en Medio Ambiente y Ciencia Marina (IMEDMAR-UCV), Universidad Católica de Valencia SVM, C/Explanada del Puerto S/n, 03710, Calpe, Alicante, Spain \\ ${ }^{\mathrm{b}}$ Escuela de Doctorado, Universidad Católica de Valencia San Vicente Mártir, Spain \\ ${ }^{\mathrm{c}}$ Centro Oceanográfico de Baleares, Instituto Español de Oceanografía- Muelle de Poniente $\mathrm{s} / \mathrm{n}, 14$ 07015, Palma de Mallorca, Spain \\ d IRTA-Aquatic Ecosystems, Ctra. Poble Nou Km 5.5, 43540, Sant Carles de la Ràpita, Tarragona, Spain \\ e Institut Océanographique Paul Ricard, Ile des Embiez, 83140, Six Fours les Plages, France
}

The present work, which is the first comparative study of the growth of the fan mussel Pinna nobilis in the western Mediterranean, encompasses 12 populations of this species living in different environments in France and Spain. Two hundred nine shells were processed and used to obtain growth records from the posterior adductor muscle scar. Size-at-age data were fitted to the Von Bertalanffy growth model. Considerable variability in growth pa-rameters and age was detected among the populations. The results show that the only two fan mussel populations remaining in Spain, which live in an estuary and a coastal lagoon, occupy habitats that are optimal for fast growth, but individuals show low longevity, complicating the long-term conservation of the species. Multivariate analyses groups the populations into three groups (SO, EO and LG), and a general model is proposed for each group; the model can be used as an approximation to calculate the ages of individuals living in similar environments.

\section{Introduction}

Age and growth are key features in population demography and relate the trophic and demographic aspects of a system (Margalef, 1998). Within this context, growth is also a tool that can be used to estimate age based on its relationship to measurable dimensions of the studied organism. Differences in size, age and growth among bivalve populations can be related to the environmental characteristics of their habitats, such as hydrodynamic conditions and seagrass cover (Gar-cia-March et al., 2007b; Hendriks et al., 2011; Irlandi, 1996), food availability and quality (Blicher et al., 2010; Fréchette and Bourget, 1985; Ortmann and Grieshaber, 2003; Wong and Cheung, 2001), population density (van Erkom Schurink and Griffiths, 1993), temperature (Blicher et al., 2010; Schwartzmann et al., 2011) and grain size (De la Huz et al., 2002) among other possible factors. Demographic features have been successfully used to estimate the best habitats for the reintroduction or protection of endangered species (Fariñas-Franco et al., 2016).

Extensive demographic studies of the fan mussel Pinna nobilis that include measurement of age and growth have rarely been conducted because age and growth estimations were costly and/or unreliable until recently (Basso et al., 2015). The methodology proposed by Garcia-March et al. (2011), which uses the growth records of the posterior adductor muscle scar (PAMS) observed in radial sections of the shell, enabled the development of more precise and less costly age and growth estimations of this species (Kersting and Garcia-March 2017). For years, the fan mussel has been considered an endangered Mediterranean endemic species, and it is included in the 'Habitats Directive' and in the ANNEX II of the Barcelona Convention. A recent mass mortality event (MME) that resulted in almost 100\% mortality of the species along the Spanish Mediterranean coasts (Vázquez-Luis et al., 2017; García-March et al., 2019, in revision) resulted in its reclassification to "endangered with extinction" in Spain (Orden TEC/596/2019, Ministerio para la transición Ecológica, 8 April 2019). This MME was very likely caused by a recently discovered parasitic protozoan, Haplosporidium pinnae (Cat-anese et al., 2018), although Carella et al. (2019) also found a 
Mycobacterium in samples of diseased fan mussels that may have contributed to the die-off. The mortality is presently spreading through the Mediterranean with lethal consequences (Katsanevakis et al., 2019; Panarese et al., 2019), leaving the species in a critical situation; only isolated populations remaining unaffected in specific reservoirs such as coastal marine lagoons and deltas remain unaffected (García-March et al., in revision).

$P$. nobilis is the largest Mediterranean bivalve mollusk, reaching a size of up to $120 \mathrm{~cm}$ (Vicente, 1990; Zavodnik et al., 1991). It has a long life span that can exceed 45 years (Rouanet et al., 2015). Furthermore, it displays the fastest shell growth rate reported for any bivalve (Richardson et al., 2004). This growth is especially noticeable during the first months of life (Hendriks et al., 2012; Kersting and Garcia-March 2017). Shell growth in this species is highly variable among pop-ulations (Richardson et al., 1999) and within the same population living at different depths (Garcia-March et al., 2007a). Oceanographic differ-ences among sites (e.g., depth, temperature, hydrodynamics and food availability) may have a great influence on the species' growth rate (Garcia-March et al., 2007a, 2007b; Hendriks et al., 2011; Katsanevakis, 2007). An understanding of the age and growth parameters of fan mussel populations inhabiting different conditions and their relationship to environmental variables such as hydrodynamics will improve the quality of demographic studies and the implementation of protection measures (Basso et al., 2015; Garcia-March et al., 2011; Richardson et al., 2004).

The present work represents the first comparative study of 12 fan mussel statistical populations (referred to hereinafter as populations, Ludwig and Reynolds, 1988) living under various environmental conditions and located in protected and unprotected areas of the western Mediterranean (France and Spain). The relationship between growth parameters estimated using the method of Garcia-March et al. (2011) and the animals' habitat conditions is evaluated on the basis of differences in the site (lagoon, estuary or open sea), depth (shallow or deep) and hydrodynamic regime (sheltered and exposed) of the habitat. The protection status of the marine areas (protected or unprotected) was also considered. The results of this study will permit a better understanding of fan mussel ecology in relation to environmental factors such as wave exposure, especially considering that the IPCC (2018) panel predicts that increased weather extremes will occur in the future. The results will also help in the planning of effective restocking actions, the evaluation of the resilience of remaining populations and the creation of new ma-rine protected areas specifically designed for the recovery of $P$. nobilis populations.

\section{Material and methods}

\subsection{Shell collections and study}

The study was conducted using 12 populations of $P$. nobilis shells from the Spanish and French coasts (western Mediterranean) (Fig. 1); the shells had been stored in various laboratories. The empty shells were gathered from locations that were subject to different hydrodynamic and environmental conditions and various levels of governmental pro-tection ( 5 of the locations have protected status), although all of the locations are presently included in the Natura2000 Network.

A total of 209 shells were used for growth parameter calculations. When possible, 20 shells, including shells that represented the entire size range available, were chosen from each population for analysis. How-ever, some collections included many small individuals less than 3 years old; shells from these individuals were not used in the growth parameter calculations. Therefore, the final sample size ranged from 8 to 21 shells per population (Table 1 ).

Populations 1 (Freus, $\mathrm{N}=16$ ) and 2 (Gandulf, $\mathrm{N}=16$ ) were obtained at the Marine Protected Area of Cabrera National Park (Balearic Islands) from exposed and sheltered sites, respectively, within Posidonia oceanica meadows and at a depth range of 5-10 m. Population 3 (Tabarca, $\mathrm{N}=20$ ) was obtained from the Tabarca Island Marine Protected Area, the first Marine Protected Area of Fishery Interest (RMIP) of Spain, created in 1986. The shells were sampled in a $P$. oceanica meadow located on the western part of the island in a site sheltered from main

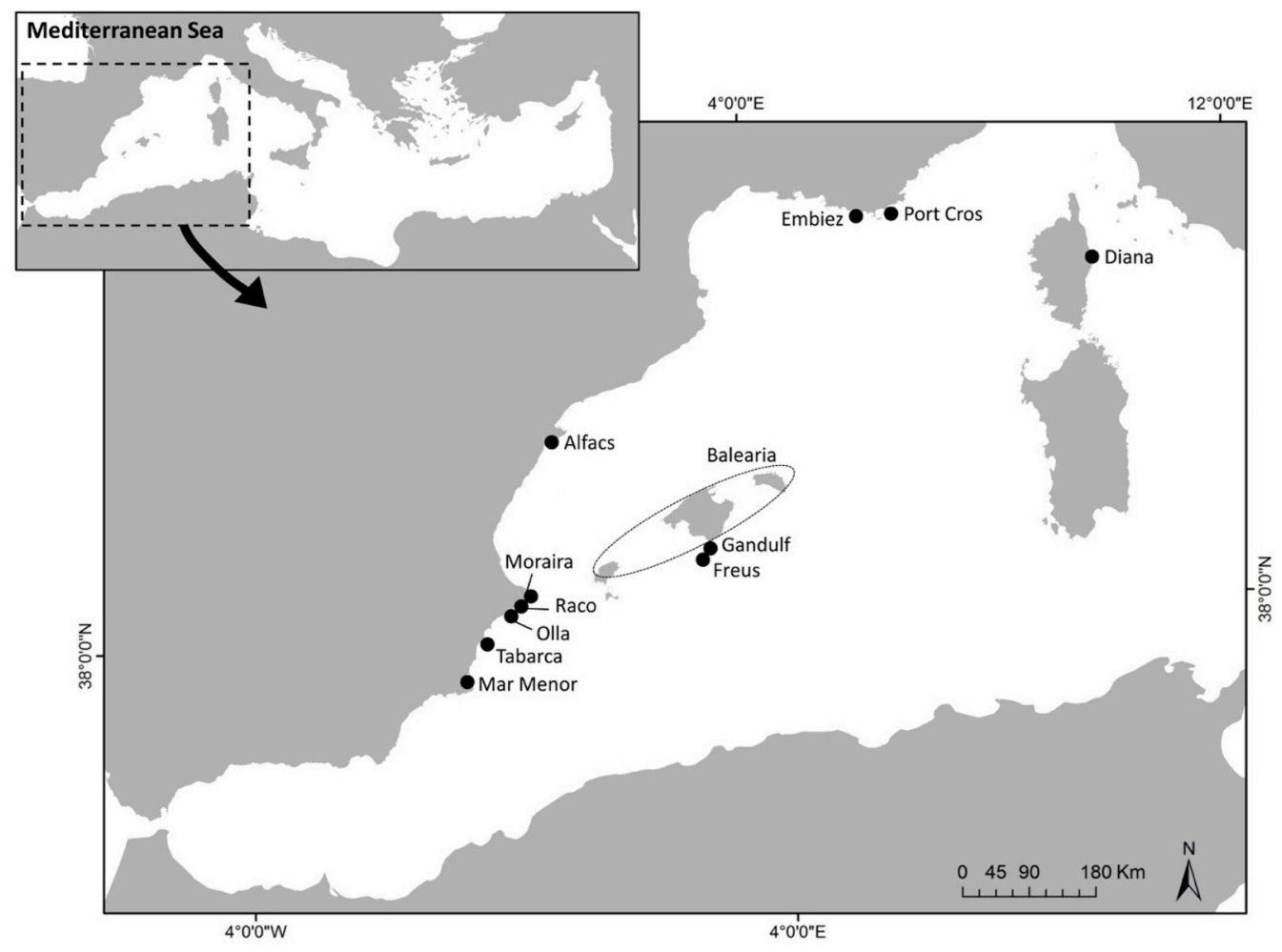

Fig. 1. Locations of the populations used in the present study. 
Table 1

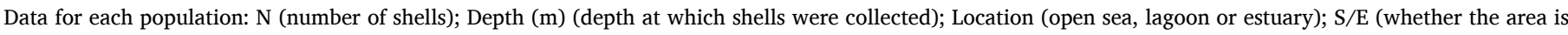

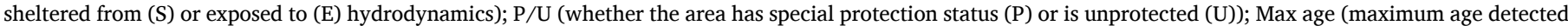

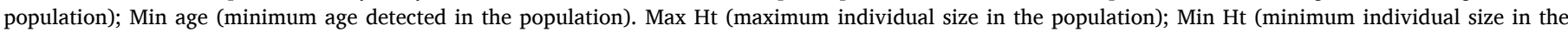

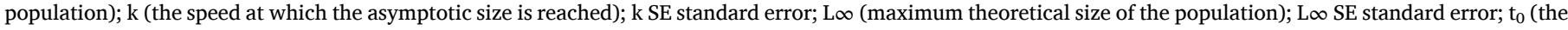

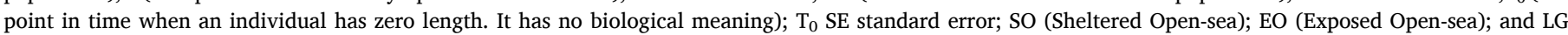
(Lagoons).

\begin{tabular}{|c|c|c|c|c|c|c|c|c|c|c|c|c|c|c|c|}
\hline Population & $\mathrm{N}$ & $\begin{array}{l}\text { Depth } \\
\text { (m) }\end{array}$ & Location & $\begin{array}{l}\text { S/ } \\
\text { E }\end{array}$ & $\begin{array}{l}\mathrm{P} / \\
\mathrm{U}\end{array}$ & $\begin{array}{l}\text { Max age } \\
\text { (years) }\end{array}$ & $\begin{array}{l}\text { Min age } \\
\text { (years) }\end{array}$ & $\begin{array}{l}\text { Max Ht } \\
\text { (cm) }\end{array}$ & $\begin{array}{l}\text { Min Ht } \\
(\mathrm{cm})\end{array}$ & $\mathrm{k}$ & k SE & $\begin{array}{l}\mathrm{L} \infty \\
(\mathrm{cm})\end{array}$ & $\begin{array}{l}\mathrm{L} \infty \\
\mathrm{SE}\end{array}$ & to & t0 SE \\
\hline Freus & 16 & 5-10 & Open sea & $\mathrm{E}$ & $\mathrm{P}$ & 14 & 5 & 44.7 & 28.8 & 0.21 & 0.02 & 43.9 & 1.3 & -0.57 & 0.23 \\
\hline Gandulf & 16 & $5-10$ & Open sea & $S$ & $\mathrm{P}$ & 27 & 5 & 65.6 & 38.5 & 0.19 & 0.01 & 62.4 & 1.5 & -0.05 & 0.13 \\
\hline Tabarca & 20 & $5-10$ & Open sea & $S$ & $P$ & 27 & 4 & 68.8 & 30.9 & 0.19 & 0.01 & 58.7 & 1.4 & -0.40 & 0.12 \\
\hline PortCros & 19 & $10-25$ & Open sea & $S$ & $\mathrm{P}$ & 38 & 3 & 68.0 & 29.3 & 0.15 & 0.00 & 65.4 & 1.9 & -0.95 & 0.12 \\
\hline Olla & 19 & 5-10 & Open sea & $\mathrm{E}$ & $\mathrm{P}$ & 11 & 4 & 51.5 & 18.7 & 0.29 & 0.02 & 39.9 & 1.9 & 0.24 & 0.13 \\
\hline Mar Menor & 17 & $0-2$ & Lagoon & $S$ & $\mathrm{U}$ & 9 & 3 & 58.0 & 30.0 & 0.37 & 0.04 & 58.2 & 2.5 & -0.06 & 0.13 \\
\hline Moraira & 21 & $5-7$ & Open sea & $\mathrm{E}$ & $\mathrm{U}$ & 17 & 6 & 49.1 & 25.6 & 0.21 & 0.01 & 45.6 & 1.0 & -0.88 & 0.12 \\
\hline Raco & 18 & $5-10$ & Open sea & $S$ & $\mathrm{U}$ & 21 & 4 & 68.2 & 20.9 & 0.24 & 0.01 & 60.7 & 1.7 & 0.12 & 0.10 \\
\hline Diana & 14 & $0-2$ & Lagoon & $S$ & $\mathrm{U}$ & 12 & 3 & 47.8 & 26.8 & 0.24 & 0.04 & 56.9 & 3.9 & -0.04 & 0.21 \\
\hline Embiez & 8 & $0-2$ & Lagoon & $S$ & $\mathrm{U}$ & 6 & 4 & 54.3 & 26.3 & 0.30 & 0.05 & 56.0 & 4.5 & 0.28 & 0.12 \\
\hline Balearia & 21 & 20 & Open sea & $S$ & $\mathrm{U}$ & 26 & 3 & 79.1 & 39.0 & 0.13 & 0.00 & 65.5 & 1.9 & -1.78 & 0.16 \\
\hline Alfaques & 20 & $0-2$ & Estuary & $S$ & $\mathrm{U}$ & 15 & 5 & 59.8 & 42.8 & 0.18 & 0.01 & 75.0 & 2.6 & -0.03 & 0.16 \\
\hline SO & 113 & & & & & & & & & 0.17 & 0.00 & 63.1 & 0.8 & -0.67 & 0.06 \\
\hline EO & 56 & & & & & & & & & 0.23 & 0.01 & 43.0 & 0.8 & -0.47 & 0.09 \\
\hline LG & 39 & & & & & & & & & 0.30 & 0.03 & 56.5 & 2.3 & -0.05 & 0.11 \\
\hline
\end{tabular}

storms at $5-10 \mathrm{~m}$ depth within the $P$. oceanica meadow. Population 4 (Port-Cros, $\mathrm{N}=20$ ) was obtained from Port-Cros National Park (northwestern Mediterranean, Var, France), one of the oldest marine national parks in the Mediterranean Sea, created in 1963. Beginning in 1969, a monitoring program was initiated in the "Champ de La Palud" with the main purpose of controlling the evolution of fan mussels in this area (Vicente et al., 1980). Empty shells were sampled in this area; most were obtained from a dead matte of $P$. oceanica between 15 and $25 \mathrm{~m}$ in depth. The shells of population 5 (Olla, $N=19$ ) were obtained at the southwest portion of a small islet in the 'Parque Natural Marítimo Terrestre Serra Gelada' near the town of Altea (Alicante, Spain) in a $P$. oceanica meadow in an exposed area at 5-10 $\mathrm{m}$ depth. Population 6 (Mar Menor, $\mathrm{N}=17$ ) was obtained from the Mar Menor hyperhaline coastal lagoon (Murcia, Spain), which is included in the RAMSAR Convention. It is one of the largest Mediterranean coastal lagoons. The maximum depth of the lagoon is $7 \mathrm{~m}$; the empty shells were collected at 2-6 $\mathrm{m}$ depth from a muddy bed covered by Caulerpa prolifera. Shells of Population 7 (Mor-aira, $\mathrm{N}=21$ ) were obtained from a bay that is oriented southwards, delimited by the capes of Moraira and Ifach (Alicante, Spain) and exposed to southerly waves (Garcia-March and Marquez-Aliaga, 2007). The shells were sampled within a dense $P$. oceanica meadow at 5-7 $\mathrm{m}$ depth. Population 8 (Racó, $\mathrm{N}=18$ ) was obtained at Calpe (Alicante, Spain) on the western side of the "Peñon de Ifach" at 5-10 m depth in a $P$. oceanica meadow sheltered from the main waves by the crag. Popu-lation 9 (Diana lagoon, $\mathrm{N}=14$ ) was obtained from the east coast of Corsica (France). Diana lagoon is the deepest of the Corse lagoons $(11 \mathrm{~m}$ depth); however, the densest $P$. nobilis populations, from which the empty shells were sampled, occur in Cymodocea nodosa meadows at a depth of 0.5-1 m (De Gaulejac and Vicente, 1990). Shells from Population 10 (Embiez, $\mathrm{N}=8$ ) were obtained from the Le Brusc lagoon located at the southern end of the Embiez archipelago. This shallow lagoon is sheltered from the open sea by a $P$. oceanica barrier reef. The sampling site was covered by a disperse $P$. oceanica meadow and has a maximum depth of $1.5 \mathrm{~m}$. Population 11 (Balearia, $\mathrm{N}=21$ ) groups individuals from various areas around the Balearic Islands located at 20 $\mathrm{m}$ depth. Population 12 (Alfacs, $\mathrm{N}=20$ ) was obtained from an estuarine bay in the southern part of the Ebro Delta (Cataluña, Spain). This area features dispersed patches of Caulerpa prolifera and Cymodocea nodosa, and the empty shells were sampled at depths between 0.2 and $1.2 \mathrm{~m}$.

With respect to their environmental characteristics, the sampled populations came from shallow areas in the open sea that are mainly protected from hydrodynamics that are harmful to fan mussels (Gandulf, Raco, and Tabarca), from areas sufficiently deep to be unaffected by hydrodynamics harmful to fan mussels (Port-Cros and Balearia), from shallow areas in the open sea that are exposed to hydrodynamics harmful to fan mussels (Olla, Moraira and Freus), from coastal marine lagoons (Embiez, Diana and Mar Menor), and from estuaries (Alfacs).

\subsection{Shell processing}

The shells were treated according to the methodology described by Garcia-March et al. (2011). The dorsal nacre lobe of one valve of each shell was embedded in epoxy resin and cut into 3 to 5 8-cm-long dorsal-to-ventral sections (the portion of the shell lost in the cut was ca. $0.4 \mathrm{~mm}$ ). Each section was cut radially across the PAMS. One side of the cross-section was polished to 1200 grit and mounted on a glass slide, and a thin sheet (ca. $300 \mu \mathrm{m}$ ) was cut using a precision sectioning saw (Buehler Isomet low-speed saw). The free surface of the slide was pol-ished down to 1200 grit (Garcia-March et al., 2011). The thin sheets produced in this way allow microstructural analysis of growth records using a magnifying binocular lens and optical microscopy (Garcia--March and Marquez-Aliaga, 2007).

To estimate growth parameters, the positions of the PAMS was related to the total size of the shell $(\mathrm{Ht})$ using linear regression analysis. Based on the good linear relationship between $\mathrm{Ht}$ and the length of the dorsal nacre lobe (DNL), an equation was fitted to the data for each population (Garcia-March and Marquez-Aliaga, 2007; Garcia-March et al., 2011; Richardson et al., 1999; Vicente et al., 1980). The sizes of the individuals when each growth record was deposited were also calculated.

As typically occurs with fan mussels, the calcite layer is incomplete in the anterior part of the shell, especially in adult specimens. For this reason, some of the oldest annual increments may be missing (Garcia-March et al., 2011). Given that the calcite width at each annual increment is a function of the number of years over which calcite was deposited (Garcia-March and Marquez-Aliaga, 2007), the number of missing records could be obtained by comparing the calcite widths in the 3 or 4 oldest records for all individuals within a population.

\subsection{Growth model}

Size-at-age data were fitted to the Von-Bertalanffy growth function using the non-linear mixed effects model (Vigliola and Meekan, 2009) considering $\mathrm{L}_{\infty}$ as random and $\mathrm{t}_{0}$ and $\mathrm{k}$ as fixed (Garcia-March et al., 2011). This method fits any nonlinear model to longitudinal data with great flexibility in modeling the within-group correlations that are often 
present in such data (Vigliola and Meekan, 2009).

Non-parametric multidimensional scaling (MDS) was used as the ordination method for exploring affinities among populations according to maximum age, Max_Ht (maximum individual size in the population), $\mathrm{L}_{\infty}$ and $\mathrm{K}$. The similarity matrix, which was calculated by the Bray-Curtis index based on square-root transformed data, was used to construct bivariate MDS plots. The multivariate analysis was carried out using the PRIMER v.5 package (Clarke and Gorley, 2001).

The Z-test (Clogg et al., 1995) was used to determine the significance of the differences in the parameters $\mathrm{L} \infty$ and $\mathrm{K}$ among the groups, applying the Bonferroni correction $(? ?=0.0083)$. The groups were also compared with the population studied by GarciaMarch et al. (2011) in Moraira Bay, which was located in the same area as one of the pop-ulations in the present study but at a different depth range (11-13 $\mathrm{m}$ depth).

The size differences among groups of different ages were tested by applying Tukey's honestly significant differences (HDS) test to the data for size-at-age obtained previously (see 2.2. Shell processing). The ages compared ranged from 2 years (the first age for which data were available for most individuals) to 11 years (when only SO and EO could be compared). From age 7 onwards, there were insufficient data from LG for comparison (only SO, EO and Alfacs could be compared), and from age 11 onwards there were insufficient data from Alfacs (only SO and EO could be compared).

\section{Results}

A remarkable variability in age and growth parameters was observed (Fig. 2). The maximum age of empty shells ranged from 6 years in the Embiez lagoon to 38 years in Port-Cros. The maximum shell length measured (Max_Ht) ranged from $44.7 \mathrm{~cm}$ in Freus to 79.1 $\mathrm{cm}$ in Balearia. In the Von-Bertalanffy growth function, parameter $\mathrm{K}$, the speed at which the asymptotic size is reached, varied between 0.15 in Port-Cros and 0.37 in Mar Menor Lagoon, while $\mathrm{L}_{\infty}$ varied between $39.5 \mathrm{~cm}$ in Olla and $75.0 \mathrm{~cm}$ in Alfacs. The data for each population are presented in Table 1.

Multivariate analyses revealed 4 groups within the studied populations with a 95\% of similarity (Fig. 3): 1) Sheltered Open-sea -SO(Gandulf, Raco, Tabarca, Balearia and Port-Cros); 2) Exposed Open-sea - EO - (Olla, Moraira and Freus); 3) Lagoons - LG - (Embiez, Diana and
Mar Menor), located in coastal marine lagoons; and 4) Alfacs, located in an estuary.

Except for the Alfacs group, which included only one population, a general model was calculated for the groups identified by the multivariate analysis (SO, EO and LG; Fig. 4 and Table 1$)$ : SO $(\mathrm{N}=113)$ with $\mathrm{K}=0.17$ and $\mathrm{L}_{\infty}=63.1 \mathrm{~cm}$ (Eq. (1)); $\mathrm{LG}(\mathrm{N}=39)$ with $\mathrm{K}=$ 0.30 and $\mathrm{L} \infty=56.5 \mathrm{~cm} \quad$ (Eq. (2)); and $\mathrm{EO} \quad(\mathrm{N}=56)$ with $\mathrm{K}=$ 0.23 and $\mathrm{L}_{\infty}=43.0 \mathrm{~cm}$ (Eq. (3)). The standardized residuals in relation to size for each of the groups showed no relevant trends and few outliers; most of the data fell within 2 standard deviations of the mean (SO $=94.1 \%$, EO $=95.3 \%$, LG $=94.8 \%$, and Alfacs $=$ 92.62\%), indicating good fit of the models (Fig. 5).

$L_{t}=63.1+\left(1-e^{-0.17 \cdot(t+0.67)}\right)$

$L_{t}=56.5+\left(1-e^{-0.30 \cdot(t+0.05)}\right)$

$L_{t}=43.0+\left(1-e^{-0.23 \cdot(t+0.47)}\right)$

The two-sided p-values for the Z-test results (Table 2) showed significant differences in Lo between SO-EO, SO-Alfacs, SO-Mor, EO-LG, EO-Alfacs, EO-Mor, LG-Alfacs and Alfacs-Mor and significant differences in $\mathrm{K}$ between SO-EO, SO-LG, EO-Alfacs, EO-Mor, LG-Alfacs and LG-Mor.

Tukey's HDS found significant differences among the groups through the years. EO shows significant differences for all groups and all years except Alfacs at age 2. LG shows significant differences from SO in all years, and SO and Alfacs show significant differences from ages 5 to 10 . The results of Tukey's HDS analysis are presented in Table 3.

\section{Discussion}

The present work constitutes the first comparative growth study of the endangered species $P$. nobilis in 12 different locations in the western Mediterranean. Considerable variability in growth and longevity due to environmental conditions and protection status was detected. Multivariate analysis grouped the populations into four different groups, each of which shares common environmental characteristics. The groups are: 1) Sheltered and Shallow Open-sea SO (Gandulf, Raco, Tabarca, Balearia and Port-Cros populations), located in shallow and deep areas in the open sea but mainly protected from hydrodynamics that are harmful to fan mussels; 2) Exposed open-sea EO (Olla, Moraira and Freus

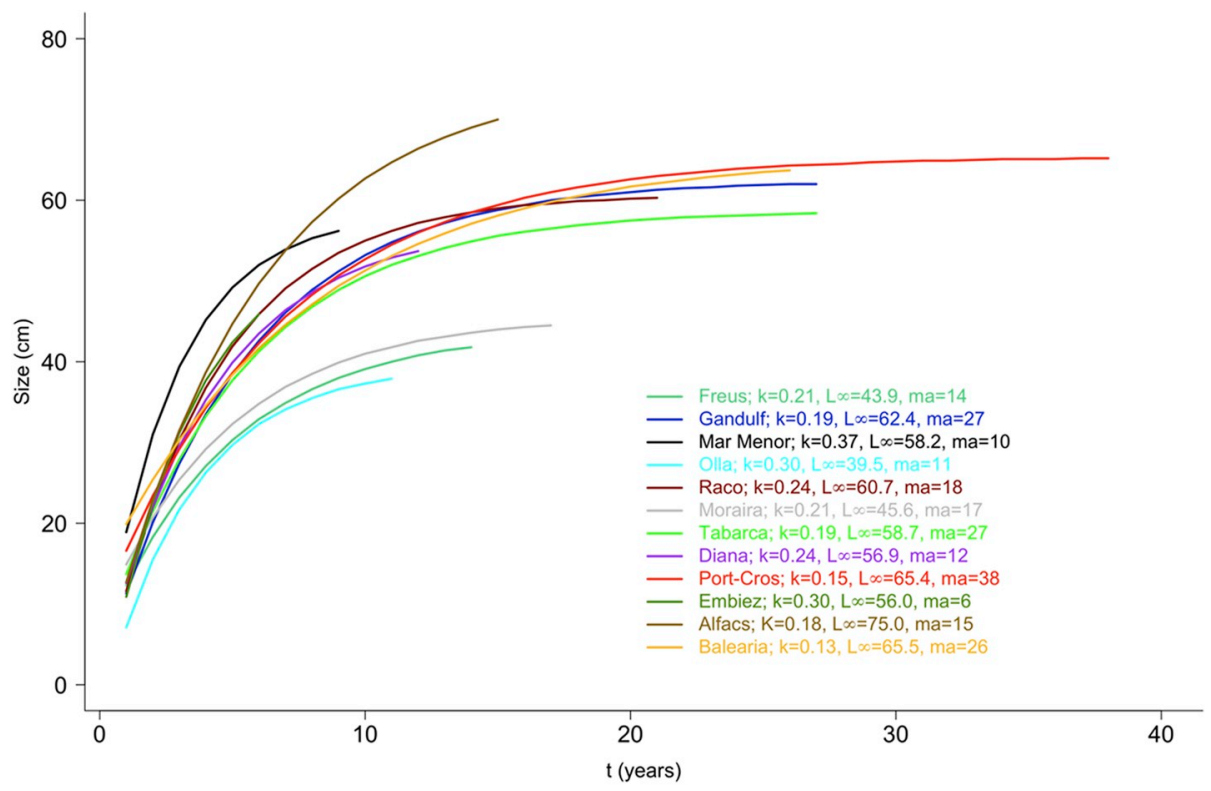

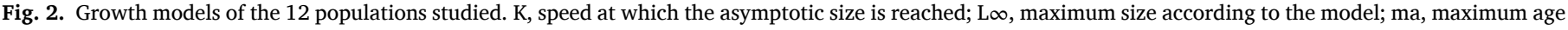
detected among the individuals studied in the population. 


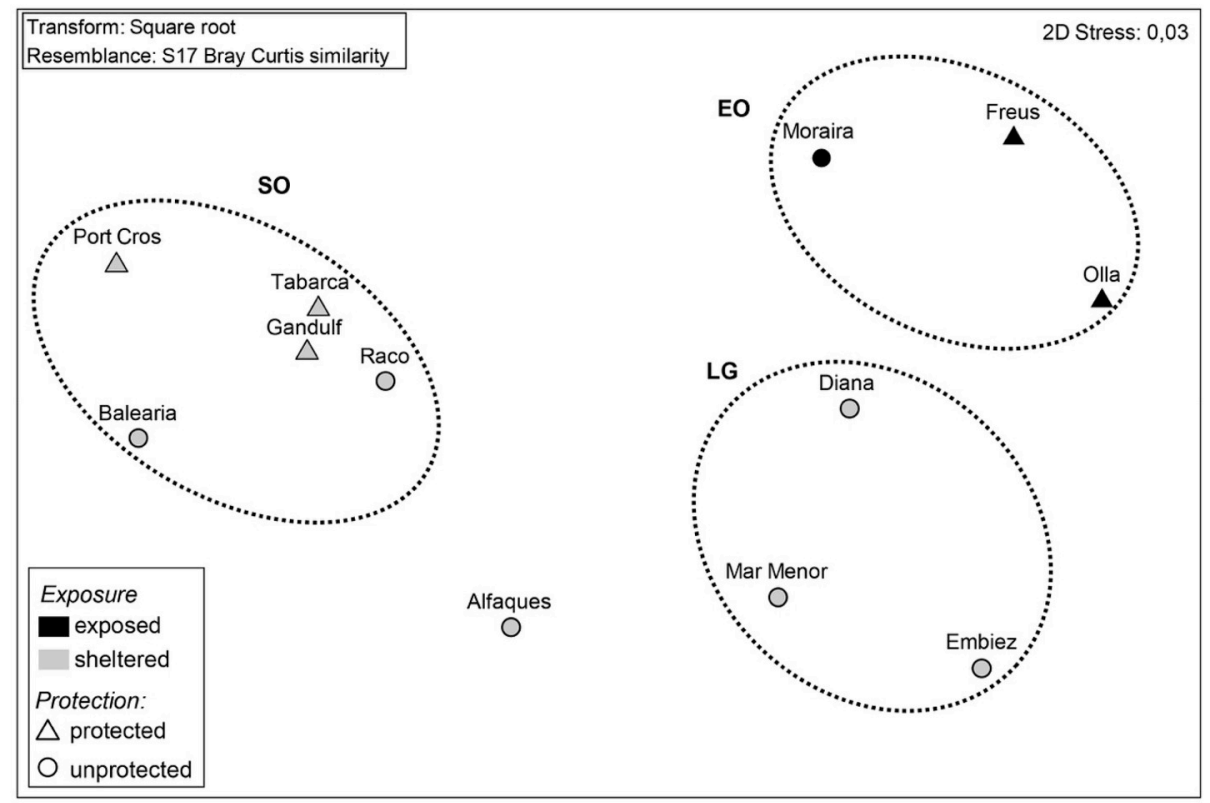

Fig. 3. Two-dimensional MDS plot for the 12 studied P. nobilis populations by exposure and protection based on square root transformed and Bray-Curtis similarity of maximum age, Max_Ht, Lo and K. Groups are based in a 95\% of similarity: SO: Sheltered Open-sea, EO: Exposed Open-sea, and LG: Lagoons.

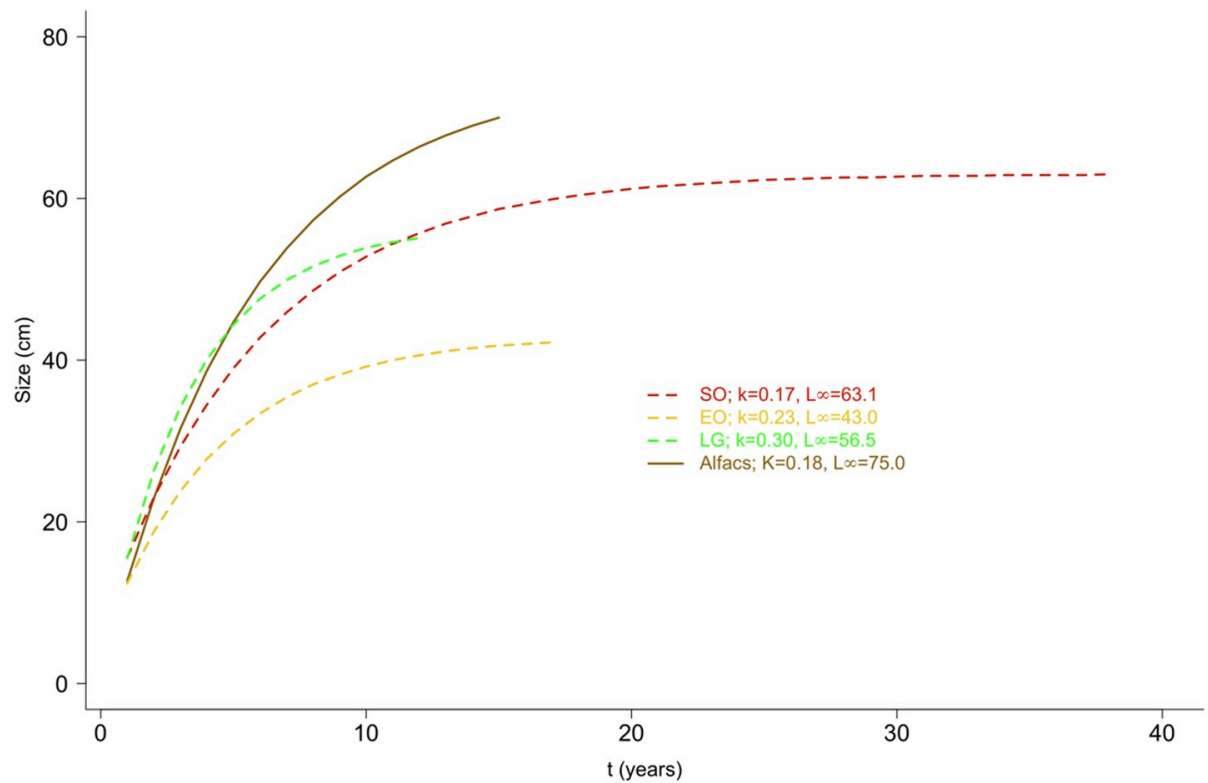

Fig. 4. General growth models for the three classifications according to multivariate analysis results (Sheltered Open-sea -SO-; Exposed and Shallow Open-Sea -EO-; Lagoon -LG-; Alfacs, the only population inhabiting an estuary).

populations), located in shallow areas in the open sea and exposed to hydrodynamics harmful to fan mussels; 3) Lagoons LG (Embiez, Diana and Mar Menor populations), located in coastal marine lagoons; and 4) Alfacs, separated from the other groups and the only population inhabiting an estuary.

Three general growth models were established based on multivariate analysis. Although calculation of specific models for each population would be advisable, in the absence of specific population models, the general models proposed here could be used as a reference for other $P$. nobilis populations living in similar habitats. Estuaries such as Delta del Ebro could be grouped in a different general growth model; however, because Alfacs was the only population sampled from an estuarine environment, further research that includes more populations living in deltaic environments should be conducted to support its singularity as a model.

EO populations show lower growth rates and Lo than other populations. According to Deudero et al. (2015); Garcia-March et al. (2007b), the effects of intermittent high hydrodynamics or continuous moderate hydrodynamics could increase mortality and limit growth by causing stress and shell breakage. Moreover, Garcia-March et al. (2016) studied the in situ gaping activity of fan mussels and found that bimodal currents such as those generated by waves cause greater disturbance to $P$. nobilis individuals than unimodal currents such as tides, even at lower water speeds. The effect of these forces decreases with increasing depth and with the presence of Posidonia oceanica and is influenced by seabed topography (Garcia-March et al., 2007b; Hendriks et al., 2011). There-fore, it is hypothesized that the maximum size of EO populations may be constrained by hydrodynamics, while SO and LG populations may grow 
SO

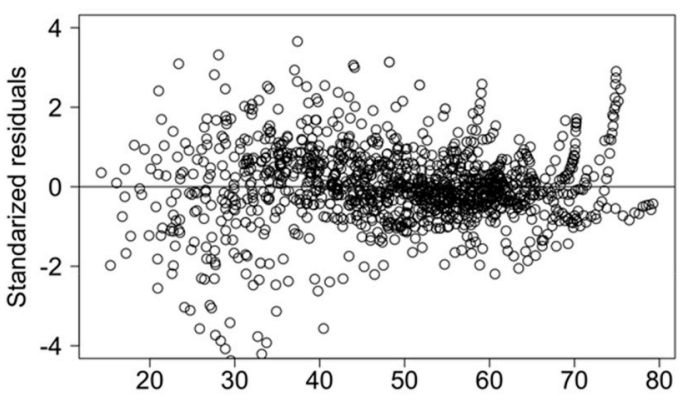

LG

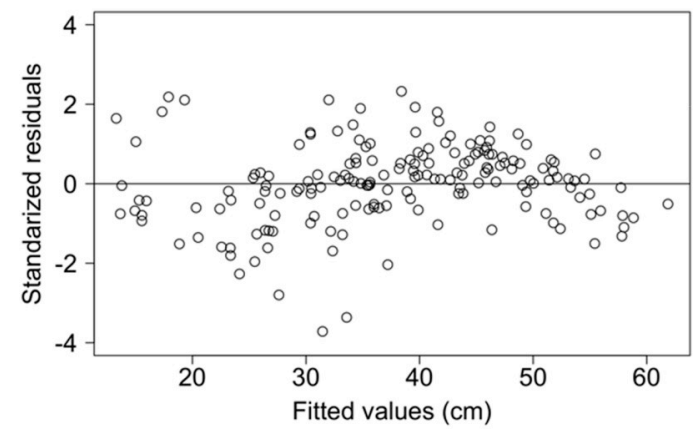

EO

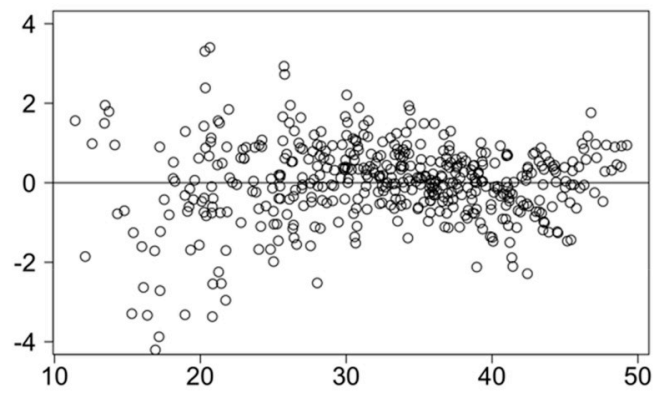

Alfacs

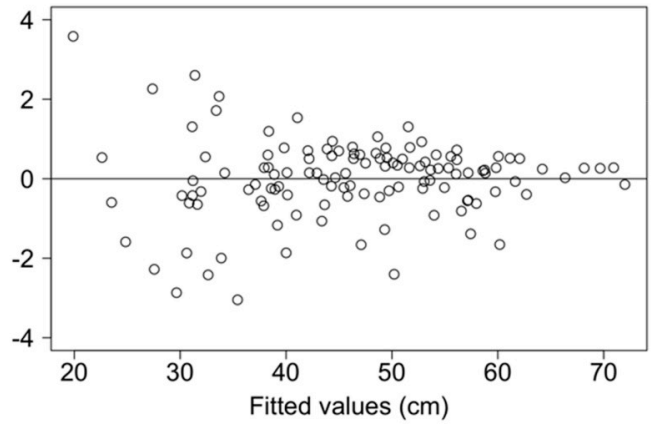

Fig. 5. Standardized residuals in relation to size for each of the groups resulting from multivariate analysis.

Table 2

Z-test results for comparison of $\mathrm{L} \infty$ and $\mathrm{k}$ values among the groups established by multivariate analysis and Mor (the population studied by Garcia-March et al.(2011) in Moraira).

\begin{tabular}{llllll}
\hline & Lo & & & & \\
\cline { 2 - 5 } & SO & EO & LG & Alfacs & Mor \\
\hline SO & & $* * *$ & 0.017 & $* * *$ & $* * *$ \\
EO & & $* * *$ & $* * *$ & $* * *$ \\
LG & & & $* * *$ & 0.765 \\
Alfacs & $\mathrm{k}$ & & & $* * *$ \\
\hline & SO & EO & LG & Alfacs & Mor \\
\cline { 2 - 5 } & & $* * *$ & $* * *$ & 0.5 & 0.146 \\
SO & & 0.016 & $* *$ & $* * *$ \\
EO & & & $* * *$ & $* * *$ \\
LG & & & & 0.244 \\
Alfacs & & & & &
\end{tabular}

$* * * \mathrm{p}$ value $<0.001 ; * \mathrm{p}$ value $<0.01 ; * \mathrm{p}$ value $<0.05$.

to larger sizes because they are typically sheltered from detrimental hydrodynamics.

Environmental conditions tend to be more stable in deep areas. Although shallow areas are protected from hydrodynamics, they are more prone to anthropogenic impacts and climatic extremes. Therefore, it seemed reasonable to expect that deep populations in different areas of the western Mediterranean Sea would have more similarities in their growth parameters than more closely situated populations living in shallower sheltered areas. However, the populations within the SO group show similar growth patterns despite living at different depths. This supports the idea that, effectively, in the open sea, hydrodynamics may be a determinant of fan mussel growth, constraining shell size in populations that inhabit exposed sites. When the effect of hydrodynamics on fan mussels is low due because the populations are sheltered or are situated at greater depth, other environmental factors would exert a similar effect on the species independently of location.

In this regard, the population studied by Garcia-March et al. (2007a)
Table 3

Results of Tukey's honestly significant differences test among groups. From age 7 onwards, there were insufficient data from LG for comparison (only SO, EO and Alfacs could be compared), and from age 11 onwards there were insufficient data for Alfacs (only SO and EO could be compared).

\begin{tabular}{|c|c|c|c|c|c|c|c|c|}
\hline & \multicolumn{4}{|l|}{2 years } & \multicolumn{4}{|c|}{7 years } \\
\hline & so & EO & LG & Alfacs & so & EO & LG & Alfacs \\
\hline so & & $* *$ & * & 0.936 & & $* * * *$ & - & $* * * *$ \\
\hline $\mathrm{EO}$ & & & $* * *$ & 0.161 & & & - & $* * *$ \\
\hline LG & & & & 0.906 & & & & - \\
\hline \multicolumn{3}{|c|}{3 years } & \multicolumn{6}{|c|}{8 years } \\
\hline so & & $* * *$ & $* * *$ & 0.463 & & $* * *$ & - & $* * *$ \\
\hline EO & & & $* * *$ & $* * * *$ & & & - & $* * *$ \\
\hline LG & & & & 0.085 & & & & - \\
\hline \multicolumn{3}{|c|}{4 years } & \multicolumn{6}{|c|}{9 years } \\
\hline so & & $* * * *$ & $* * *$ & 0.072 & & $* * * *$ & - & $* * *$ \\
\hline $\mathrm{EO}$ & & & $* * * *$ & $* * * *$ & & & - & * \\
\hline LG & & & & 0.398 & & & & - \\
\hline \multicolumn{3}{|c|}{5 years } & \multicolumn{6}{|c|}{10 years } \\
\hline so & & $* * *$ & $* * *$ & $* *$ & & $* * *$ & - & 0.078 \\
\hline EO & & & $* * *$ & $* * *$ & & & - & $* * *$ \\
\hline LG & & & & 0.775 & & & & - \\
\hline \multicolumn{3}{|c|}{6 years } & \multicolumn{6}{|c|}{11 years $^{\circ}$} \\
\hline so & & $* * *$ & $* * *$ & $* * * *$ & & $* * *$ & - & - \\
\hline EO & & & $* * *$ & $* * *$ & & & - & - \\
\hline LG & & & & 0.977 & & & & - \\
\hline
\end{tabular}

***p value $<0.001 ; * * \mathrm{p}$ value $<0.01 ;$ *p value $<0.05 ;-$ insufficient data for comparison.

${ }^{\circ} \mathrm{SO}$ and EO showed significant differences from ages 11 to 14, the last age in EO for which there were sufficient data for comparison.

in Moraira (Alicante, Spain), which is located at a depth of 11-13 m, shows a growth model with $\mathrm{L} \infty$ higher than that of the EO population but lower than that of the SO population and k lower than that of the EO population but similar to that of the SO population. This population 
could be in a situation intermediate between those of the deep (20 m) and exposed populations and may be partially affected by hydrodynamics. On the other hand, $L \infty$ and growth rate appear to be independent of the legal protection of the area, considering that the multivariate analysis groups populations independently of such protection and no differences are found between protected and unprotected populations.

The Alfacs and LG populations inhabit confined waters. These populations are notable for their higher growth rate from 5 to 9 years of age and Lo (Alfacs) and their higher growth rate from 2 to 7 years of age (LG) compared to the other populations studied (Fig. 4). The specific conditions that exist in these paralic environments could be responsible for these extremes. Higher food availability compared with open sea, could explain this discrepancy as has been demonstrated for growth and survival differences of $P$. nobilis living in eutrophic versus oligotrophic environments (Alomar et al., 2015). Ebro Delta waters are nutrient-enriched by inputs from agricultural irrigation (Falco et al., 2010; Mañosa et al., 2001; Prado, 2018; Sierra et al., 2002). The same occurs for coastal lagoons, which are also affected by the increase in the population in coastal areas and by agriculture and industry. These im-pacts, in conjunction with environmental conditions such as low water circulation and long water residence, make these areas more susceptible to nutrient enrichment (Kennish and Paerl, 2010). This situation has been remarkable during recent years in Mar Menor lagoon, which has undergone some eutrophication (Garcia-Ayllon, 2018; Pérez-Ruzafa et al., 2005b; Velasco et al., 2006). The reason that $\mathrm{L} \infty$ for the Alfacs population is $18.5 \mathrm{~cm}$ larger than the value predicted by the general growth model for LG is unknown. The salinity regimes of paralic environments show higher fluctuations than those of open sea environments due to their environmental characteristics (Kennish and Paerl, 2010). These fluctuations, however, are not mirrored by the growth trends observed in the fan mussel populations living within these areas. Salinity in Alfacs is usually lower than that in the open sea due to precipitation and discharge of irrigation channels (Solé et al., 2009). Mar Menor is a hyperhaline lagoon that can reach salinity levels of up to 51 ps $\mu$ (Pérez-Ruzafa et al., 2005a). The Diana and Embiez lagoons show lower salinity levels than Mar Menor but often oscillate below and above open-sea levels following the wet and dry seasons (Burgeot et al., 1996; De Gaulejac and Vicente, 1990; Rouanet et al., 2009). Taken together, the data suggest that environmental factors other than salinity may have more weight in determining the growth trends observed in the paralic environments. Additional studies of more fan mussel populations living in paralic environments should be conducted, however, before definitely ruling out the possibility that fan mussel growth is affected by salinity.

Remarkable variation in survival and maximum age is also found among the studied populations. The EO, LG and Alfacs populations show the lowest maximum ages (17, 12 and 15 years) of the studied in-dividuals. In exposed areas, the effect of hydrodynamic conditions, as previously noted, could be responsible for lower survival, but hydro-dynamic conditions are usually gentle in lagoon/estuarine environ-ments. Furthermore, lagoon/estuarine populations are the only populations in which $\mathrm{L}_{\infty}$ is higher than Max_Ht; this could indicate that in these locations individuals die before reaching maximum size and/or that the posterior part of the shell has been broken and reconstructed, making it appear smaller in size. Shell breakage caused by intense boat traffic, which often hits the individuals and breaks their shells (Prado et al., 2014) could be an explanation for the condition of the Alfacs population, in which 19 of 20 shells showed conspicuous reconstruction marks. Multiple factors could be affecting the lifespans of lagoon/es-tuarine populations. 1) Compared to open-sea ecosystems, lagoon/es-tuarine ecosystems present more stressful extreme conditions (CañedoArguielles et al., 2018). During the winter and the rainy season, the temperature and salinity may approach the tolerance limit for the species. The same occurs during summer, when high temperatures and high salinity levels occur (except in the case of the Ebro Delta, where salinity decreases in summer due to agriculture discharges) and oxygen concentrations may reach dangerously low levels (Cataudella et al.,
2015). 2) The presence of chemical contaminants produced by anthropogenic activities is also common in these environments (Kennish and Paerl, 2010), as reported for the Ebro estuary (Köck et al., 2010; Mañosa et al., 2001; Solé et al., 2000), Mar Menor (CañedoArgüelles et al., 2018; Pérez-Ruzafa et al., 2000) and the Diana lagoon (Burgeot et al., 1996; Galgani et al., 2006). 3) In some taxa, rapid growth and large body size appear to be related to shorter lifespan (Metcalfe and Monaghan, 2003), although this remains to be demonstrated for $P$. nobilis. Either separately or together, these factors could limit the life expectancy of fan mussel populations living in lagoon/estuarine environments. Accord-ingly, the general LG model should be used with caution. The oscilla-tions that occur in coastal lagoons due to natural conditions and anthropogenic effects could induce stochastic variations in fan mussel growth. The same could be true for estuarine areas such as Alfacs.

Anthropogenic effects go beyond contamination, and other threats such as anchoring, habitat loss and shell poaching have been proven to decimate fan mussel populations (Basso et al., 2015; Deudero et al., 2015; Hendriks et al., 2013; Katsanevakis et al., 2011; VázquezLuis et al., 2014, 2015). Accordingly, it should be highlighted that the maximum ages detected, 38 and 34 years, were found in specimens obtained from the Port-Cros National Park, which was created in 1963. The other marine reserves, the National Marine Reserve of Tabarca and the Cabrera Archipelago Maritime-Terrestrial National Park, are rela-tively recent (they were created in 1986 and 1991, respectively); these reserves hosted individuals 27 years old, similar to the age of the re-serves at the time of shell sampling. The maximum ages of the sampled populations suggest a possible positive effect of the protection of marine areas on $P$. nobilis longevity, although additional studies should be conducted to conclusively determine the association of protection status with fan mussel longevity.

The current situation of $P$. nobilis is critical. The recent MME affecting the species is devastating almost all fan mussel populations (Katsanevakis et al., 2019; García-March et al., in revision). Only some populations living in confined waters such as lagoons and estuaries are surviving, and the reasons for this are unknown. Among the populations addressed in the present study, only the populations at Mar Menor, Alfacs (García-March et al., in revision), Embiez and Diana (Nardo Vicente, pers. com.) remain alive today, whereas the other populations have experienced $100 \%$ mortality (García-March et al., in revision). In the current situation, one strategy to ensure the future of the species would be captive breeding and artificial reintroduction of juveniles. Of the studied populations, Port-Cros, Gandulf and Tabarca appear to be the most optimal locations for $P$. nobilis reintroduction based on the sizes and ages reached by the individuals and the protection status of the sites. However, the lack of resistant individuals and the possible long-term presence of disease could make these areas unavailable for the reintro-duction of fan mussels. This leaves lagoons and estuaries as the only hope for the short term survival of individuals under natural conditions and for the reintroduction of juveniles. The growth parameters of the populations living in these environments indicate that they may be good areas for the growth of the species during the first years of life, but populations living in lagoons and, to a lesser extent, in the Ebro Delta, appear to be unstable in the long term. The short lifespan of fan mussels in these environments suggests that these populations rely on abundant recruitment and that the survival of introduced individuals could be constrained in the long term. Furthermore, the instability of these eco-systems due to both natural and anthropogenic factors (Kennish and Paerl, 2010; Reizopoulou and Nicolaidou, 2007) could lead to sudden collapse of these populations. In the Mar Menor lagoon, eutrophication has been threatening the ecosystem for a long time, and it spiked during the summer of 2015 and the spring of 2016, resulting in the collapse of the lagoon (Garcia-Ayllon, 2018; PérezRuzafa et al., 2019). Further-more, natural resettlement of fan mussels in coastal lagoons or deltas recovered after a collapse would be impossible due to the lack of con-nectivity among populations unless manipulative reintroduction of fan mussels were undertaken (García-March et al., in revision). On the other 
hand, Callinectes sapidus, an invasive Mediterranean crab introduced from the Atlantic, is spreading throughout the Mediterranean, has been recently observed in Delta del Ebro (Fuentes et al., 2019), and has colonized Mar Menor for several years (Castejón and Guerao, 2013; Mancinelli et al., 2017). This voracious crustacean could also become a threat to $P$. nobilis juveniles in these reservoirs. Therefore, as also suggested by growth parameters and longevity, the survival of fan mussel populations living in these reservoirs could be endangered in the absence of connectivity with other populations. Urgent measures should be implemented to increase the long-term stability of these areas in the future and to preserve $P$. nobilis from extinction.

The data obtained in the present study can also be used to predict the resilience of fan mussels in the context of climate change, which may produce a scenario of weather extremes and associated wave action in the Mediterranean Sea (IPCC 2018). It is expected that the surviving populations in exposed areas will experience increasing hydrodynamic stress in the future, probably resulting in individuals dying younger and growing to lower sizes.

Further research is necessary to expand the models to other environmental conditions and to adjust for the inherent morphological variations in $P$. nobilis shells. Shell shape appears to be related to the environmental conditions under which the individuals grow, and it could be used bidirectionally. On one hand, it might be possible to separate growth models within a population according to shell shape. It is hypothesized that more accurate growth rate and age estimations could be achieved in this way. On the other hand, the method could be used together with growth parameter estimations as an indicator of environmental conditions.

\section{Acknowledgments}

This research was partially funded by the Fundación de la Comunidad Valenciana para el Medio Ambiente under the project "Estudio del creci-miento del mayor bivalvo del Mediterráneo, la nacra (Pinna nobilis), en las costas de la Comunidad Valenciana" and by the Prince Albert II of Monaco Foundation under the project BF/HEM 15-1662 "The study, protection and possible breeding of pen shell (Pinna nobilis) in the Boka Kotorska Bay”. Maite Vázquez-Luis was supported by a postdoctoral contract with Juan de la CiervaIncorporación (IJCI-2016-29329) of Ministerio de Ciencia, Innovación y Universidades. We are grateful to Ministerio de Agricultura, Alimentación y Medio Ambiente (RMIP-SGM- MAGRAMA) and the Conselleria de Infraestructuras, Territorio y Medio Ambiente (CITMA) (Generalitat Valenciana), who gave permission for the collection and sampling of shells. We thank the Delta del Ebro Natural Park for its collaboration and for permission to work within its protected area. Special thanks are extended to Felio Lozano and the staff of Tab-arca Island Marine Reserve and to Santiago Jimenez of the Foundation Instituto de Ecología Litoral for their help in the collection of shells from Tabarca Island. The shells from Olla in Serra Gelada were provided partially by Asociación Poseidón, which also provided assistance in finding the remaining shells from this population. The shells from Moraira were donated by the Marine Biology Laboratory of the University of Valencia. We are grateful to Institut Oceanographique Paul Ricard (shells from Embiez, Port-Cros and Diana) and to Michella Tundo, Maria del Toro, Alberto Martínez, Gwendaline Provenzani, Sophie Piaentini, Silvia Fraissinet and Martina Scanu for their help in processing the shells.

\section{Appendix A. Supplementary data}

Supplementary data to this article can be found online at https://doi. org/10.1016/j.marenvres.2019.104795.

\section{References}

Alomar, C., Vazquez-Luis, M., Magraner, K., Lozano, L., Deudero, S., 2015. Evaluating stable isotopic signals in bivalve Pinna nobilis under different human pressures. J. Exp. Mar. Biol. Ecol. 467, 77-86.

Basso, L., Vazquez-Luis, M., Garcia-March, J.R., Deudero, S., Alvarez, E., Vicente, N., Duarte, C.M., Hendriks, I.E., 2015. The Pen Shell, Pinna nobilis: a review of population status and recommended research priorities in the Mediterranean Sea. Adv. Mar. Biol. 71 71, 109-160.

Blicher, M.E., Rysgaard, S., Sejr, M.K., 2010. Seasonal growth variation in Chlamys islandica (Bivalvia) from sub-Arctic Greenland is linked to food availability and temperature. Mar. Ecol. Prog. Ser. 407, 71-86.

Burgeot, T., Woll, S., Galgani, F., 1996. Evaluation of the micronucleus test on Mytilus galloprovincialis for monitoring applications along French coasts. Mar. Pollut. Bull. $32,39-46$

Cañedo-Argüielles, M., Boix, D., Quintana, X., Gascón, S., Ibáñez, C., Caiola, N., 2018. Management and Restoration of Mediterranean Coastal Lagoons in Europe.

Carella, F., Aceto, S., Pollaro, F., Miccio, A., Iaria, C., Carrasco, N., Prado, P., De Vico, G., 2019. A mycobacterial disease is associated with the silent mass mortality of the pen shell Pinna nobilis along the Tyrrhenian coastline of Italy. Sci. Rep. 9, 2725.

Castejón, D., Guerao, G., 2013. A new record of the American blue crab, Callinectes sapidus Rathbun, 1896 (Decapoda: Brachyura: portunidae), from the Mediterranean coast of the Iberian Peninsula. BioInvasion Record. 2, 141-143.

Catanese, G., Grau, A., Maria Valencia, J., Rafael Garcia-March, J., Alvarez, E., VazquezLuis, M., Deudero, S., Darriba, S., Carballal, M.J., Villalba, A., 2018. Haplosporidium pinnae sp. nov., a haplosporidan parasite associated with mass mortalities of the fan mussel, Pinna nobilis, in the Western Mediterranean Sea. J. Invertebr. Pathol. 157, 9-24. https://doi.org/10.1016/j.jip.2018.07.006.

Cataudella, S., Crosetti, D., Massa, F., 2015. Mediterranean Coastal Lagoons: Sustainable Management and Interactions Among Aquaculture, Capture Fisheries and the Environment, vol. I. General Fisheries Commission for the Mediterranean. Studies and Reviews.

Clarke, K., Gorley, R., 2001. PRIMER (Plymouth Routines in Multivariate Ecological Research) V5: User Manual/tutorial. Primer-E Ltd, Plymouth, pp. 1-91.

Clogg, C.C., Petkova, E., Haritou, A., 1995. Statistical methods for comparing regression coefficients between models. Am. J. Sociol. 100, 1261-1293.

De Gaulejac, B., Vicente, N., 1990. Ecologie de Pinna nobilis (L.) mollusque bivalve sur les côtes de Corse. Essais de transplantation et expériences en milieu contrôlé. Haliotis $10,83-100$.

De la Huz, R., Lastra, M., López, J., 2002. The influence of sediment grain size on burrowing, growth and metabolism of Donax trunculus L.(Bivalvia: donacidae). J. Sea Res. 47, 85-95.

Deudero, S., Vázquez-Luis, M., Álvarez, E., 2015. Human stressors are driving coastal benthic long-lived sessile fan mussel Pinna nobilis population structure more than environmental stressors. PLoS One 10, e0134530.

Falco, S., Niencheski, L., Rodilla, M., Romero, I., del Río, J.G., Sierra, J.P., Mösso, C., 2010. Nutrient flux and budget in the Ebro estuary. Estuar. Coast Shelf Sci. 87, 92-102.

Fariñas-Franco, J.M., Sanderson, W.G., Roberts, D., 2016. Phenotypic differences may limit the potential for habitat restoration involving species translocation: a case study of shape ecophenotypes in different populations of Modiolus modiolus (Mollusca: Bivalvia). Aquat. Conserv. Mar. Freshw. Ecosyst. 26, 76-94.

Fréchette, M., Bourget, E., 1985. Food-limited growth of Mytilus edulis L. in relation to the benthic boundary layer. Can. J. Fish. Aquat. Sci. 42, 1166-1170.

Fuentes, M., Torrent, L., Barrera, S., Boix, D., 2019. Rapid invasion of the American blue crab Callinectes sapidus rathbun, 1896 in the north-east of the iberian peninsula. BioInvasions Record. 8.

Galgani, F., Chiffoleau, J.-F., Orsoni, V., Costantini, L., Boissery, P., Calendini, S., Andral, B., 2006. Chemical contamination and sediment toxicity along the coast of Corsica. Chem. Ecol. 22, 299-312.

Garcia-Ayllon, S., 2018. The Integrated Territorial Investment (ITI) of the Mar Menor as a Model for the Future in the Comprehensive Management of Enclosed Coastal Seas. Ocean \& Coastal Management.

Garcia-March, J.R., Marquez-Aliaga, A., 2007. Pinna nobilis L., 1758 age determination by internal shell register. Mar. Biol. 151, 1077-1085.

Zavodnik, D., Hrs-Brenko, M., Legac, M., 1991. Synopsis on the fan shell Pinna nobilis L. in the eastern Adriatic Sea. In: Boudouresque, C.F., M.A., Gravez, V. (Eds.), Les Espèces Marines à Protéger en Méditerranée. GIS Posidonie Publications, Marseille, pp. 169-178.

Garcia-March, J.R., Garcia-Carrascosa, A.M., Cantero, A.L.P., Wang, Y.G., 2007. Population structure, mortality and growth of Pinna nobilis Linnaeus, 1758 (Mollusca, Bivalvia) at different depths in Moraira bay (Alicante, Western Mediterranean). Mar. Biol. 150, 861-871.

Garcia-March, J.R., Perez-Rojas, L., Garcia-Carrascosa, A.M., 2007. Influence of hydrodynamic forces on population structure of Pinna nobilis L., 1758 (Mollusca : Bivalvia): the critical combination of drag force, water depth, shell size and orientation. J. Exp. Mar. Biol. Ecol. 342, 202-212.

Garcia-March, J.R., Marquez-Aliaga, A., Wang, Y.G., Surge, D., Kersting, D.K., 2011. Study of Pinna nobilis growth from inner record: how biased are posterior adductor muscle scars estimates? J. Exp. Mar. Biol. Ecol. 407, 337-344.

Garcia-March, J.R., Jiménez, S., Sanchis, M.A., Monleon, S., Lees, J., Surge, D., TenaMedialdea, J., 2016. In situ biomonitoring shows seasonal patterns and environmentally mediated gaping activity in the bivalve, Pinna nobilis. Mar. Biol. $163,1-12$. 
Hendriks, I.E., Cabanellas-Reboredo, M., Bouma, T.J., Deudero, S., Duarte, C.M., 2011. Seagrass meadows modify drag forces on the shell of the fan mussel Pinna nobilis. Estuar. Coasts 34, 60-67.

García-March, J.R., Tena-Medialdea, J., Henandis-Caballero, S., Vázquez-Luis, M.,

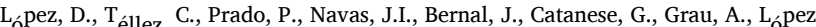
Sanmartín, M., Nebot-Colomer, E., Ortega, A., Planes, S., Kersting, Mortimoeniez, S. Himdnikss; Casalduero, F., Pérez, M., Izquierdo,

A., Sjaetrez, N., Sanmarti, N., Guimerans Mt, Crespo, J.L., Barrajon, A., VÁlleancėa, B.,M., Poyres?, $\mathrm{C}_{\text {. }}$, Morage, T., Deudero, marine species affected by a highly isfe20ive, Can higlshylethal,

disease from extinction? Biol. Conserv. Submitted for publication.

Hendriks, I.E., Basso, L., Deudero, S., Cabanellas-Reboredo, M., Álvarez, E., 2012. Relative growth rates of the noble pen shell Pinna nobilis throughout ontogeny around the Balearic Islands (Western Mediterranean, Spain). J. Shellfish Res. 31, 749-756.

Hendriks, I.E., Tenan, S., Tavecchia, G., Marba, N., Jorda, G., Deudero, S., Alvarez, E. Duarte, C.M., 2013. Boat anchoring impacts coastal populations of the pen shell, the largest bivalve in the Mediterranean. Biol. Conserv. 160, 105-113.

IPCC, 2018. Summary for Policymakers. In: global warming of $1.5^{\circ} \mathrm{C}$. An IPCC Special Report on the impacts of global warming of $1.5^{\circ} \mathrm{C}$ above pre-industrial levels and related global greenhouse gas emission pathways. In: Zhai, V., Pörtner, P., Roberts, H.O., Skea, D., Shukla, J., Pirani, P.R., Moufouma-Okia, A., Péan, W., Pidcock, C., Connors, R., Matthews, S., Chen, J.B.R., Zhou, Y., Gomis, X., Lonnoy, M. I. Maycock, E., Tignor, T., Waterfield, M., T. (Eds.), The Context of Strengthening the Global Response to the Threat of Climate Change, Sustainable Development, and Efforts to Eradicate Poverty. Masson-Delmotte. World Meteorological Organization, Geneva, Switzerland, p. 32.

Irlandi, E., 1996. The effects of seagrass patch size and energy regime on growth of a suspension-feeding bivalve. J. Mar. Res. 54, 161-185.

Katsanevakis, S., 2007. Growth and mortality rates of the fan mussel Pinna nobilis in Lake Vouliagmeni (Korinthiakos Gulf, Greece): a generalized additive modelling approach. Mar. Biol. 152, 1319-1331.

Katsanevakis, S., Poursanidis, D., Issaris, Y., Panou, A., Petza, D., Vassilopoulou, V., Chaldaiou, I., Sini, M., 2011. Protected" marine shelled molluscs: thriving in Greek seafood restaurants. Mediterr. Mar. Sci. 12, 429-438.

Katsanevakis, S., Tsirintanis, K., Tsaparis, D., Doukas, D., Sini, M., Athanassopoulou, F., Dolygas, M., Tontis, D., Koutsoubas, D., Bakopoulos, V., 2019. The cryptogenic parasite Haplosporidium pinnae invades the Aegean Sea and causes the collapse of Pinna nobilis populations. Aquat. Invasions 14.

Kennish, M.J., Paerl, H.W., 2010. Coastal Lagoons: Critical Habitats of Environmental Change. CRC Press.

Kersting, D.K., Garcia-March, J.R., 2017. Long-term assessment of recruitment, early stages and population dynamics of the endangered Mediterranean fan mussel Pinna nobilis in the Columbretes Islands (NW Mediterranean). Mar. Environ. Res. 130, 282-292.

Köck, M., Farré, M., Martínez, E., Gajda-Schrantz, K., Ginebreda, A., Navarro, A., de Alda, M.L., Barceló, D., 2010. Integrated ecotoxicological and chemical approach for the assessment of pesticide pollution in the Ebro River delta (Spain). J. Hydrol 383, 73-82.

Ludwig, J.A., Reynolds, J.F., 1988. Statistical Ecology: a Primer in Methods and Computing. John Wiley \& Sons.

Mancinelli, G., Chainho, P., Cilenti, L., Falco, S., Kapiris, K., Katselis, G., Ribeiro, F., 2017. The Atlantic blue crab Callinectes sapidus in southern European coastal waters distribution, impact and prospective invasion management strategies. Mar. Pollut. Bull. 119, 5-11.

Mañosa, S., Mateo, R., Guitart, R., 2001. A review of the effects of agricultural and industrial contamination on the Ebro delta biota and wildlife. Environ. Monit.

Assess. 71, 187-205.

Margalef, R., 1998. Ecología. Omega, Barcelona, Spain.

Metcalfe, N.B., Monaghan, P., 2003. Growth versus lifespan: perspectives from evolutionary ecology. Exp. Gerontol. 38, 935-940.

Ministerio para la Transición Ecológica, 2019. Order TEC/596/2019, of 8 of April [WWW Document]. URL. https://www.boe.es/boe/dias/2019/06/05/pdfs/ BOE-A-2019-8317.pdf. accessed 16.07.19.

Ortmann, C., Grieshaber, M.K., 2003. Energy metabolism and valve closure behaviour in the Asian clam Corbicula fluminea. J. Exp. Biol. 206, 4167-4178.

Panarese, R., Tedesco, P., Chimienti, G., Latrofa, M.S., Quaglio, F., Passantino, G., Buonavoglia, C., Gustinelli, A., Tursi, A., Otranto, D., 2019. Haplosporidium pinnae associated with mass mortality in endangered Pinna nobilis (Linnaeus 1758) fan mussels. J. Invertebr. Pathol. 164, 32-37.

Pérez-Ruzafa, A., Navarro, S., Barba, A., Marcos, C., Cámara, M., Salas, F., Gutierrez, J., the Mar Menor lagoon (SE Spain). Mar. Pollut. Bull. 40, 140-151.
P érez-Ruzafa, A., Fernández, A.I., Marcos, C., Gilabert, J., Quispe, J.I., García-Charton, J. A., 2005. Spatial and temporal variations of hydrological conditions, nutrients and chlorophyll a in a Mediterranean coastal lagoon (Mar Menor, Spain). Hydrobiologia 550, 11-27.

Pérez-Ruzafa, A., Marcos, C., Gilabert, J., 2005. The Ecology of the Mar Menor Coastal Ecosystem Processes and Modeling for Sustainable Use and Development. CRC Press, Boca Ratón, Florida, pp. 392-422.

Pérez-Ruzafa, A., Campillo, S., Fernández-Palacios, J.M., García Lacunza, A., García-
Oliva, M., Ibañez, H., Pérez-Marcos, M., Pérez-Ruzafa, I., Quispe, J.I., Sala, A., 2019. Long term dynamic in nutrients, chlorophyll a and water quality parameters in a coastal lagoon during a process of eutrophication for decades, a sudden break and a relatively rapid recovery. Front. Mar. Sci. 6, 26.

Prado, P., 2018. Seagrass epiphytic assemblages are strong indicators of agricultural discharge but weak indicators of host features. Estuar. Coast Shelf Sci. 204, 140-148.

Prado, P., Caiola, N., Ibáñez, C., 2014. Habitat use by a large population of Pinna nobilis in shallow waters. Sci. Mar. 78, 555-565.

Reizopoulou, S., Nicolaidou, A., 2007. Index of Size Distribution (ISD): a Method of Quality Assessment for Coastal Lagoons, Lagoons and Coastal Wetlands in the Global Change Context: Impacts and Management Issues. Springer, pp. 141-149. Richardson,

C.A., Kennedy, H., Duarte, C.M., Kennedy, D.P., Proud, S.V., 1999. Age and growth of the fan mussel Pinna nobilis from south-east Spanish Mediterranean seagrass (Posidonia oceanica) meadows. Mar. Biol. 133, 205-212.

Richardson, C.A., Peharda, M., Kennedy, H., Kennedy, P., Onofri, V., 2004. Age, growth rate and season of recruitment of Pinna nobilis (L) in the Croatian Adriatic determined from Mg : Ca and Sr : Ca shell profiles. J. Exp. Mar. Biol. Ecol. 299, 1-16. Rouanet, E., Bonnefont, J.-L., Durand, R., 2009. Site Natura 2000 FR 9302001 "Lagune du Brusc" - Document d'Objectifs - Tome 1 : Diagnostics écologiques et socioéconomiques, enjeux et objectifs de conservation hiérarchisés. Institut Océanographique Paul Ricard, Convention cadre Etat/ Communauté d'agglomération Toulon Provence Méditerranée, p. 183.

Rouanet, E., Trigos, S., Vicente, N., 2015. From youth to death of old age: the 50-year story of a Pinna nobilis fan mussel population at Port-Cros Island Port-cros National Park, Provence, Mediterranean Sea. Sci. Rep. Port-Cros Natl. Park 29, 209-222.

Schwartzmann, C., Durrieu, G., Sow, M., Ciret, P., Lazareth, C.E., Massabuaua, J., 2011. In situ giant clam growth rate behavior in relation to temperature: a one-year coupled study of high-frequency noninvasive valvometry and sclerochronology. Limnol. Oceanogr. 56, 1940-1951.

Sierra, J., Sánchez-Arcilla, A., Del Río, J.G., Flos, J., Movellan, E., Mösso, C., Martınez, R., Rodilla, M., Falco, S., Romero, I., 2002. Spatial distribution of nutrients in the Ebro estuary and plume. Cont. Shelf Res. 22, 361-378.

Solé, M., Porte, C., Barcelo, D., Albaiges, J., 2000. Bivalves residue analysis for the assessment of coastal pollution in the Ebro Delta (NW Mediterranean). Mar. Pollut. Bull. 40, 746-753.

Solé, J., Turiel, A., Estrada, M., Llebot, C., Blasco, D., Camp, J., Delgado, M., FernándezTejedor, M., Diogène, J., 2009. Climatic forcing on hydrography of a mediterranean

bay (Alfacs bay). Cont. Shelf Res. 29, 1786-1800.

van Erkom Schurink, C., Griffiths, C., 1993. Factors affecting relative rates of growth in four South African mussel species. Aquaculture 109, 257-273.

Vázquez-Luis, M., March, D., Álvarez, E., Álvarez-Berastegui, D., Deudero, S., 2014. Spatial distribution modelling of the endangered bivalve Pinna nobilis in a Marine Protected Area. Mediterr. Mar. Sci. 15, 626-634.

Vázquez-Luis, M., Borg, J.A., Morell, C., Banach-Esteve, G., Deudero, S., 2015. Influence of boat anchoring on Pinna nobilis: a field experiment using mimic units. Mar. Freshw. Res. 66, 786-794.

Vázquez-Luis, M.`̉ Álvarez, E., Barrajón, A., García-March, J.R., Grau, A., Hendriks, I.E., Deudero, S., 2017. S.O.S. Pinna nobilis: a mass mortality event in western Mediterranean Sea. Front. Mar. Sci. 4, 109.

Velasco, J., Lloret, J., Millán, A., Marin, A., Barahona, J., Abellán, P., SánchezFernández, D., 2006. Nutrient and particulate inputs into the Mar Menor lagoon (SE Spain) from an intensive agricultural watershed. Water Air Soil Pollut. 176, 37-56. Vicente, N., 1990. Estudio ecológico y protección del molusco lamelibranquio Pinna nobilis L. 1758 en la costa mediterránea. Iberus 9, 269-279.

Vicente, N., Moreteau, J., Escoubet, P., 1980. Etude de l'evolution d'une population de Pinna nobilis L.(Mollusque Eulamelibranche) au large de l'anse de la Palud (Parc National de Port-Cros). Trav. Sci. Parc Natl. Port-Cros 6, 39-67.

Vigliola, L., Meekan, M.G., 2009. The Back-Calculation of Fish Growth from Otoliths, Tropical Fish Otoliths: Information for Assessment, Management and Ecology. Springer, pp. 174-211.

Wong, W., Cheung, S., 2001. Feeding rates and scope for growth of green mussels, Perna viridis (L.) and their relationship with food availability in Kat O, Hong Kong. Aquaculture 193, 123-137. 